\title{
35. COMPARISONS OF DIATOM BIOCOENOSES WITH HOLOCENE SEDIMENT ASSEMBLAGES IN PRYDZ BAY, ANTARCTICA ${ }^{1}$
}

\author{
Dean A. Stockwell, ${ }^{2}$ Sung-Ho Kang, ${ }^{3}$ and Greta A. Fryxell ${ }^{3}$
}

\begin{abstract}
Quantitative and qualitative examinations of the planktonic diatom population of Prydz Bay, East Antarctica, were conducted during Ocean Drilling Program Leg 119. Water column production was intense, as evidenced by high concentrations of chlorophyll $a$ (ranging from 40.0 to $576.5 \mathrm{mg} \mathrm{Chl} a \mathrm{~m}^{-2}$ ) and by high diatom abundances (ranging from 3.76 $\times 10^{10}$ to $2.9 \times 10^{11}$ cells $\mathrm{m}^{-2}$ ). Water column biomass was primarily dominated by three ice-related pennates: Nitzschia closterium, $N$. cylindrus, and $N$. curta. Together, these three diatoms accounted for $64 \%-96 \%$ of the water column assemblage.

Sediment diatom assemblages mirrored this intense water column production, with valve numbers ranging from 3.4 $\times 10^{7}$ to $6.8 \times 10^{9}$ valves $\mathrm{g}^{-1}$ sediment. The genus Nitzschia typically formed $70 \%$ of the diatom thanatocoenose. $N$. curta and $N$. cylindrus together accounted for $34.6 \%-78.3 \%$ of the total assemblage. The heavily silicified resting spores of Chaetoceros were also an important component of these sediments (accounting for $8 \%-34 \%$ of the total assemblage).
\end{abstract}

\section{INTRODUCTION}

Sediments of the Antarctic continental shelf have been characterized by Kozlova (1966), Edwards and Goodell (1969), and Lisitzin $(1962,1972)$ as being terrigenous and glacially derived. These terrigenous, iceberg sediments consisting of silt-clayey deposits surround Antarctica extending seaward from the shoreline for 500-640 km (Kozlova, 1966). Within such sediments, diatom remnants may constitute $30 \%-60 \%$ of the sedimentary matter. This type of clayey deposit, greatly enriched in diatom frustules, has been found to characterize Prydz Bay, Antarctica (Lisitzin, 1960; Kozlova, 1966). Diatom concentrations are reportedly high within these regional oozes, approaching $1 \times 10^{8}$ frustules $\mathrm{g}^{-1}$ sediment (Kozlova, 1966).

Numerous investigations conducted since 1844 (Kozlova, 1966; Fenner et al., 1976; Schrader, 1976) have established that Antarctic phytoplankton assemblages overlying these sediments live under a unique set of environmental conditions. Phytoplankton populations are classically diatom-dominated, although Phaeocystis blooms commonly occur (Garrison et al., 1987; Fryxell and Kendrick, 1988). Combining consistently low water temperatures and abundant nutrients with small to negligible vertical density gradients, phytoplankton productivity for inshore waters appear unusually high (El-Sayed, 1970; Tilzer et al., 1985). These living phytoplankton assemblages are themselves characterized by wide regional variations in both species composition and biomass (Tilzer et al., 1985).

During Leg 119 of the Ocean Drilling Program, water column samples were collected in conjunction with the drilling of five sites in Prydz Bay, Antarctica. The study was supplementary to the investigations done on fossil diatoms within the sediment cores. Figure 1 illustrates the location of the Prydz Bay drill sites and station locations. Table 1 shows the position of the stations, sampling dates, water depth, sea surface tempera-

\footnotetext{
${ }^{1}$ Barron, J., Larsen, B., et al., 1991. Proc. ODP, Sci. Results, 119: College Station, TX (Ocean Drilling Program).

2 Marine Science Institute, P.O. Box 1267, The University of Texas at Austin, Port Aransas, TX 78373-1267, U.S.A.

3 Department of Oceanography, Texas A\&M University, College Station, TX 77843-3146, U.S.A.
}

ture, and water column chlorophyll $a$ concentrations for each station occupied. The objective of this study was to compare water column diatom populations with assemblages found in the surface sediments.

\section{METHOD OF STUDY}

Water column sampling was conducted from the service vessel, Maersk Master, in the vicinity of the five ODP drill sites (Sites 739-743) occupied from 18 January to 3 February 1988. Hydrographic measures of light penetration, chlorophyll $a$ concentrations, water temperature, salinity, and density were made with respect to depth at the 14 stations occupied (see Barron, Larsen, et al., 1989). These stations were chosen at random on a daily basis as the service vessel had time available for sampling. Quantitative phytoplankton cell counts were routinely made from discrete water column samples and integrated over the 200 $\mathrm{m}$ water column (Kang, 1989). A detailed analysis of distribution of the most abundant phytoplankton within Prydz Bay during this study is presented by Kang and Fryxell (this volume). Vertical and net hauls $(35 \mu \mathrm{m})$ were made to a depth of $200 \mathrm{~m}$ in conjunction with each hydrocast to supplement species identifications. Additionally, vertical hauls of open and closing nets (35 $\mu \mathrm{m})$ were made over the following depth intervals: $0-50 \mathrm{~m} ; 50-$ $100 \mathrm{~m}$; and $100-200 \mathrm{~m}$. The natural autofluorescence of chlorophyll was excited by UV epifluorescent microscopy on board ship (Maersk Master) in order to assess living phytoplankton cells.

Quantitative sediment samples were processed as described by Stockwell (this volume). Sediment samples were oven dried for $24 \mathrm{hr}$ at $60^{\circ} \mathrm{C}$. The dry weight of each sample was measured. The samples were acid cleaned and repeatedly washed with deionized water. Slide preparations followed the procedures of Schrader (1974) and Schrader and Gersonde (1978) with modifications as suggested by Laws (1983). Sedimentation concentrations were adjusted to represent known amounts of sediment per slide. A microscope slide of each surface sediment sample furnished data on species composition, relative species abundances, and on the number of frustules per gram of sediment. Hyrax mounts of mud-line samples were prepared on board ship or in the laboratory from preserved material using methods for planktonic samples (Simonsen, 1974). Relative proportions were determined for each drill site based on the examination of ap- 


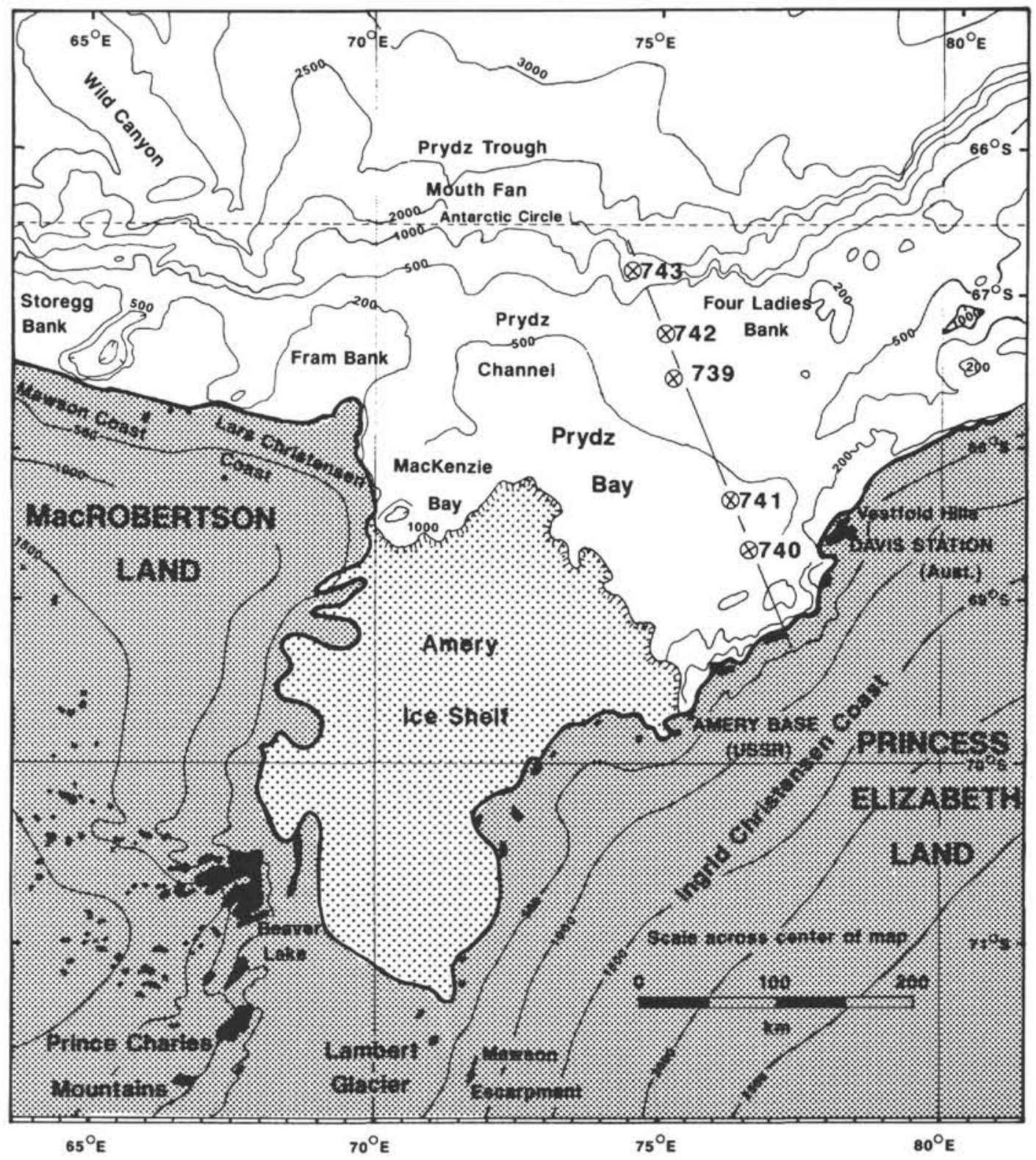

Figure 1. Prydz Bay, East Antarctica site locations occupied during Ocean Drilling Program, Leg 119. Bathymetric contours shown in meters.

proximately 300 cells recovered from near-surface sediments. Sample locations are as follows: Hole 739C, mud line; Hole 740A-1R-1, 1-2 cm, Hole 740B-1R-1, 1-2 cm; Hole 741A, mud line and Hole 741A-1R-1, 5-6 cm; Hole 742A, mud line and Hole 742A-1R-1, 4-6 cm; and Hole 743A, mud line. Counts were made on a Nikon Model SE light microscope at $650 \times$, with counting procedures described by Stockwell and Hargraves (1986).

During Leg 119 several floating sediment trap arrays were deployed as described in Biggs et al. (1989). From each trap, approximately 20 zooplankton fecal pellets were sacrificed for immediate microscopic examination. Using combined light and UV epifluorescent microscopy, individual fecal pellets were examined for recognizable diatom frustules and the natural autofluorescence of living phytoplankton cells.

\section{RESULTS}

The species composition and frequencies of diatoms found within the Prydz Bay surface sediments are shown in Table 2. Diatom concentrations were substantial and site-averaged values ranged from $3.4 \times 10^{7}$ to $6.8 \times 10^{9}$ frustules/g sediment. Large fluctuations in absolute diatom numbers, however, were observed between adjacent sites as well as within each core.

The diatom assemblage in the surface sediment reflects the more heavily silicified component of the plankton community. All five drill sites were dominated by the ribbon-colony-forming Nitzschia species. Chaetoceros resting spores, Chaetoceros setae, and fragments of Corethron criophilum were also quite common. For all sites, Chaetoceros resting spores accounted for a mean value of $7 \%$. Nitzschia curta outnumbered Nitzschia cy- 
Table 1. Prydz Bay sample location summary. Drill site, sample station, sample date, station position, site water depth, sea surface temperature, and integrated chlorophyll $a$ concentrations.

\begin{tabular}{|c|c|c|c|c|c|}
\hline Station & $\begin{array}{l}\text { Date } \\
(1988)\end{array}$ & $\begin{array}{c}\text { Position } \\
\text { (Lat./Long.) }\end{array}$ & $\begin{array}{l}\text { Water } \\
\text { depth } \\
\text { (m) }\end{array}$ & $\begin{array}{c}\text { Sea surface } \\
\text { temperature } \\
\left({ }^{\circ} \mathrm{C}\right)\end{array}$ & $\begin{array}{l}\text { Chlorophyll } a \\
\left(\mathrm{mg} \mathrm{Chl} a \mathrm{~m}^{-2} \text { ) }\right.\end{array}$ \\
\hline \multicolumn{6}{|c|}{ Outer Prydz Bay } \\
\hline $119-739-1$ & $18 \mathrm{Jan}$ & $\begin{array}{l}67^{\circ} 15^{\prime} \mathrm{S} \\
75^{\circ} 00^{\prime} \mathrm{E}\end{array}$ & & & \\
\hline $119-739-2$ & 19 Jan & $\begin{array}{l}67^{\circ} 17^{\prime} \mathrm{S} \\
75^{\circ} 04^{\prime} \mathrm{E}\end{array}$ & & & \\
\hline $119-739-3$ & 21 Jan & $\begin{array}{l}67^{\circ} 17^{\prime} \mathrm{S} \\
75^{\circ} 01^{\prime} \mathrm{E}\end{array}$ & 412 & 0.1 & 171.75 \\
\hline $119-739-4$ & 22 Jan & $\begin{array}{l}67^{\circ} 17^{\prime} \mathrm{S} \\
75^{\circ} 05^{\prime} \mathrm{E}\end{array}$ & & & \\
\hline \multicolumn{6}{|l|}{ Inner Prydz Bay } \\
\hline $119-740-5$ & 24 Jan & $\begin{array}{l}68^{\circ} 42^{\prime} \mathrm{S} \\
76^{\circ} 40^{\prime} \mathrm{E}\end{array}$ & & & \\
\hline $119-740-6$ & $25 \mathrm{Jan}$ & $\begin{array}{l}68^{\circ} 39^{\prime} \mathrm{S} \\
76^{\circ} 35^{\prime} \mathrm{E}\end{array}$ & & & \\
\hline $119-740-7$ & $26 \mathrm{Jan}$ & $\begin{array}{l}68^{\circ} 41^{\prime} \mathrm{S} \\
76^{\circ} 41^{\prime} \mathrm{E}\end{array}$ & 816 & 1.6 & 410.25 \\
\hline $119-740-8$ & 27 Jan & $\begin{array}{l}68^{\circ} 42^{\prime} \mathrm{S} \\
76^{\circ} 39^{\prime} \mathrm{E}\end{array}$ & & & \\
\hline \multicolumn{6}{|l|}{ Inner Prydz Bay } \\
\hline $119-741-9$ & $28 \mathrm{Jan}$ & $\begin{array}{l}68^{\circ} 24^{\prime} \mathrm{S} \\
76^{\circ} 21^{\prime} \mathrm{E}\end{array}$ & & & \\
\hline $119-741-10$ & $29 \mathrm{Jan}$ & $\begin{array}{l}68^{\circ} 24^{\prime} \mathrm{S} \\
76^{\circ} 20^{\prime} \mathrm{E}\end{array}$ & 561 & 1.4 & 576.50 \\
\hline \multicolumn{6}{|c|}{ Outer Prydz Bay } \\
\hline $119-742-11$ & $31 \mathrm{Jan}$ & $\begin{array}{l}67^{\circ} 32^{\prime} \mathrm{S} \\
75^{\circ} 30^{\prime} \mathrm{E}\end{array}$ & & & \\
\hline $119-742-12$ & $1 \mathrm{Feb}$ & $\begin{array}{l}67^{\circ} 34^{\prime} \mathrm{S} \\
75^{\circ} 30^{\prime} \mathrm{E}\end{array}$ & 410 & 0.6 & 78.50 \\
\hline \multicolumn{6}{|c|}{ Outer Prydz Bay } \\
\hline $119-743-13$ & 2 Feb & $\begin{array}{l}66^{\circ} 52^{\prime} \mathrm{S} \\
74^{\circ} 38^{\prime} \mathrm{E}\end{array}$ & & & \\
\hline $119-743-14$ & $3 \mathrm{Feb}$ & $\begin{array}{l}66^{\circ} 57^{\prime} \mathrm{S} \\
74^{\circ} 42^{\prime} \mathrm{E}\end{array}$ & 987 & 0.4 & 40.00 \\
\hline
\end{tabular}

lindrus, but together they contributed from $34.6 \%$ to $78.3 \%$ of the total diatom assemblage (Table 2). Nitzschia kerguelensis was also a common constituent of the sediment assemblage at $6 \%$. As reported by Krebs (1977) the major loss of diversity from water column to sediments occurred in genera having lightly silicified species. This was particularly evident of Nitzschia closterium, Nitzschia subcurvata, Chaetoceros neglectus, Chaetoceros dichaeta, Chaetoceros flexuosus, and Tropidoneis $\mathrm{sp}$. cf. vanheurckii. A total of 10 species occupied approximately $92 \%$ of the total sediment diatom assemblage.

Comparison of the relative abundance of diatom species for Prydz Bay phytoplankton samples with those from the sediment are presented in Tables 3 and 4. Integrated water column diatom abundances (whole water samples) ranged from $3.76 \times 10^{10}$ cells $/ \mathrm{m}^{2}$ at Site 743 to $2.9 \times 10^{11}$ cells $/ \mathrm{m}^{2}$ at Site 739 (Kang and Fryxell, this volume). Such differences may be attributed to differences in seasonal peak abundances. During this sampling period, Nitzschia closterium and Nitzschia cylindrus were the two dominant species ranking 1 and 2 with mean concentrations of $7.6 \times 10^{10}$ and $7.0 \times 10^{10}$ valves $/ \mathrm{m}^{2}$, respectively (Table 3 ). Net samples at each site were primarily dominated by large cells of Corethron criophilum.

Relative abundances at each drill site demonstrated the predominance of the small pennate diatoms (ca. $<20 \mu \mathrm{m}$ ) Nitzschia cylindrus, Nitzschia closterium, and Nitzschia curta (Ta- ble 5) for water column samples. Together, these three species occupied from $64 \%$ to $96 \%$ of the water column diatom assemblage. For the three offshore stations (Sites 739, 742, and 743), these three pennates were typically $>90 \%$ of the total assemblage (Table 4). For the sediments, Nitzschia curta and Nitzschia cylindrus were the two major contributors, with Nitzschia closterium completely absent. The larger-celled diatoms were primarily comprised of Chaetoceros dichaeta, Chaetoceros neglectus, Corethron criophilum, and Tropidoneis sp. cf. vanheurckii. These larger cells were also relatively more apparent at the two near-shore sites (Sites 740 and 741). This greater numerical abundance of larger cells was also coincidental with increased chlorophyll $a$ concentrations. Integrated chlorophyll $a$ values ranged from 40.0 (Site 743) to $576.5 \mathrm{mg} \mathrm{Chl} a \mathrm{~m}^{2}$ (Site 741).

Examination of vertical and horizontal net samples yielded a qualitative aspect of the phytoplankton diatom assemblage. The relatively large mesh size of the nets selectively discriminated against the small dominating pennate population observed in the whole water samples. Corethron criophilum and Chaetoceros dichaeta were the notable dominants of this net material at all five sites. Both vegetative and auxospore cells of Corethron criophilum were observed (Fig. 2). Many of these larger cells were seen that were empty or did not show autofluorescence of active chlorophyll. Figure 2 illustrates the distribution of Corethron cells with respect to three depth intervals for Sites 740, 
Table 2. Relative species abundances and overall means found in Prydz Bay sediment samples.

\begin{tabular}{|c|c|c|c|c|c|}
\hline \multirow[b]{2}{*}{ Species } & \multicolumn{4}{|c|}{ Sites } & \multirow[b]{2}{*}{743} \\
\hline & 740 & 741 & 742 & 739 & \\
\hline Actinocyclus actinochilus & 0 & 0 & 0.68 & 0 & 0.28 \\
\hline Asteromphalus hyalinus & 0 & 0.28 & 0 & 0.16 & 0.16 \\
\hline A. parvulus & 0.16 & 0 & 0 & 0 & 0.16 \\
\hline Azpeitia tabularis & 0 & 0 & 0.15 & 0 & 0.14 \\
\hline Chaetoceros atlanticus & 0 & 0 & 0 & 0 & 0.16 \\
\hline C. bulbosus & 0 & 0.14 & 0.13 & 0 & 0 \\
\hline C. criophilus & 0 & 0 & 0.26 & 0 & 0 \\
\hline C. dichaeta & 0.32 & 0.14 & 0.13 & 0 & 0 \\
\hline C. spores & 3.59 & 4.04 & 5.45 & 6.21 & 15.57 \\
\hline Corethron criophilus & 0.15 & 0 & 0.13 & 0.16 & 0 \\
\hline Dactyliosolen antarctica & 0.15 & 0.16 & 0.85 & 0.16 & 0.71 \\
\hline Eucampia antarctica var. recta & 0 & 0.30 & 0.13 & 0.63 & 0.44 \\
\hline Navicula directa & 0 & 0.30 & 0 & 0 & 0 \\
\hline Nitzschia antulata & 2.80 & 2.40 & 2.51 & 1.86 & 1.45 \\
\hline N. curta & 68.13 & 65.99 & 55.73 & 54.83 & 30.58 \\
\hline N. cylindrus & 8.91 & 7.77 & 7.49 & 7.15 & 5.79 \\
\hline N. kerguelenis & 0.32 & 0.71 & 2.06 & 3.42 & 23.55 \\
\hline$N$. lineola & 0 & 0 & 0 & 0.31 & 0.16 \\
\hline N. obliquecostata & 1.58 & 3.23 & 6.20 & 3.73 & 1.35 \\
\hline N. panduriformis & 0 & 0 & 0 & 0 & 0.14 \\
\hline N. ritscheri & 2.18 & 1.03 & 2.04 & 4.18 & 4.14 \\
\hline N. separanda & 0 & 0.45 & 0.51 & 0.47 & 1.97 \\
\hline N. spp. & 0 & 0 & 0 & 0.31 & 0 \\
\hline N. sublinearis & 0 & 0.31 & 1.88 & 1.09 & 0.74 \\
\hline N. turgiduloides & 0.62 & 0.16 & 0 & 0.47 & 0 \\
\hline Porosira glacialis (rsp) & 0.77 & 0.73 & 0.58 & 0.16 & 0.16 \\
\hline P. psudodenticulata & 0 & 0 & 0.15 & 0 & 0 \\
\hline Rhizosolenia alata & 0.16 & 0 & 0.13 & 0 & 0 \\
\hline R. hebetata f. semispina & 0.16 & 0 & 0 & 0.78 & 0.32 \\
\hline R. hebetata f. bedens & 0 & 0 & 0.15 & 0 & 0 \\
\hline Stellarima microtrias & 0.31 & 0.59 & 0.68 & 0.31 & 0 \\
\hline Synedra sp. & 0 & 0 & 0.15 & 0 & 0 \\
\hline Thalassionema sp. & 0 & 0.14 & 0 & 0 & 0 \\
\hline T. frenguelliopsis & 0 & 0.16 & 0 & 0 & 0 \\
\hline T. gracilis & 0.76 & 1.14 & 1.74 & 2.18 & 2.39 \\
\hline T. gracilis var. expecta & 0 & 0.41 & 0.26 & 0.63 & 0.14 \\
\hline T. gravida & 0 & 0.14 & 0 & 0 & 0 \\
\hline T. lentiginosa & 0 & 0.28 & 0.54 & 0.62 & 1.06 \\
\hline T. oliverana & 0 & 0 & 0.13 & 0.16 & 0 \\
\hline T. perpusilla & 0.15 & 0 & 0 & 0 & 0 \\
\hline Thalassiosira (spore) & 5.25 & 4.85 & 5.54 & 5.74 & 4.98 \\
\hline T. tumida, linear & 0 & 0 & 0.15 & 0 & 0.16 \\
\hline T. ritscheri, fasciculated & 0 & 0 & 0 & 0.16 & 0 \\
\hline T. trifulta & 0 & 0.16 & 0 & 0 & 0 \\
\hline Trichotoxon reinboldii & 0.47 & 0.44 & 0.55 & 0.47 & 0.60 \\
\hline Pennate & 0.32 & 0.32 & 0.30 & 0.62 & 0.55 \\
\hline Centric & 0 & 0.32 & 0.30 & 0.16 & 0 \\
\hline \multicolumn{6}{|l|}{ Others } \\
\hline Distephanus speculum & 0.16 & 0.14 & 0.26 & 0.31 & 0.32 \\
\hline Chrysophyte cyst & 1.99 & 2.84 & 2.40 & 2.49 & 1.86 \\
\hline Total & 99.37 & 99.97 & 100.27 & 99.86 & 99.99 \\
\hline Valves counted in sediment & 645 & 680 & 729 & 644 & 674 \\
\hline
\end{tabular}

741 , and 742. Net materials from $50 \mathrm{~m}$ to the surface appeared as a rich green soup at all three sites. Most of the Corethron cells observed $(67 \%-78 \%)$ were healthy (autofluorescing) vegetative cells. Empty or nonfluorescing cells made up an additional $21 \%-30 \%$ of the population within this depth interval. Auxospores were rarely observed in this upper layer. Relative proportions of auxospores increased with depth (5\%-15\%), being most abundant in the $50-100 \mathrm{~m}$ depth interval. However, viable or autofluorescing auxospores rarely exceeded $2 \%$ of the total population within these samples. At Site 740, the most inshore station, the relative proportions of full to empty cells changed dramatically with increasing depth. Below $50 \mathrm{~m}$, empty cells formed more than $60 \%$ of the population. The trend of increasing empty cells with increasing depth was also evident at Sites 741 and 742 . However, empty cells exceeded $60 \%$ of the population here only at greater depths (i.e., 100-200 m depth interval).

Short-term sediment trap deployments also demonstrated a rapid transport of abundant krill-like fecal pellets from surface layers (Barron, Larsen, et al., 1989). Microscopic examination of these fecal pellets revealed much breakage of valves and little cellular autofluorescence. Notable exceptions were the ingested but intact and brightly fluorescing spores of Chaetoceros neglectus. Fecal pellets from Sites 741 and 742 were also characterized by less cellular breakage and the more numerous occurrences of autofluorescing cells.

Numerous empty diatom frustules were also observed to occur in the whole water samples. The proportions of full to empty cells are suggestive of a population's state of health or grazing pressures. Distributions of these cells are discussed by 
Table 3. Ranking of mean species abundances for water column and mean ranking of species in relative abundances for the sediments of Prydz Bay, Antarctica.

\begin{tabular}{|c|c|c|}
\hline \multirow[b]{2}{*}{ Species } & \multicolumn{2}{|c|}{ Mean ranking } \\
\hline & Plankton & Sediments \\
\hline Actinocyclus actinochilus & 29 & 25 \\
\hline Asteromphalus hyalinus & & 27 \\
\hline A. parvulus & 32 & 30 \\
\hline Azpeitia tabularis & & 30 \\
\hline Chaetoceros atlanticum & 24 & 38 \\
\hline C. bulbosus & 39 & 30 \\
\hline C. convolutus & 27 & \\
\hline C. criophilus & 37 & 37 \\
\hline C. dichaeta* & 6 & 27 \\
\hline C. flexuosus & 19 & \\
\hline C. neglectus* & 3 & \\
\hline C. sp. cf. wighamii (veg)* & 10 & \\
\hline C. sp. $(\mathrm{rsp})^{*}+$ & 7 & 3 \\
\hline Corethron criophilum ${ }^{*}$ & 4 & 30 \\
\hline Dactyliosolen antarctica & & 18 \\
\hline D. tenuijunctus & 31 & \\
\hline Eucampia antarctica & 18 & 20 \\
\hline Leptocylindrus mediterraneus & 35 & \\
\hline Navicula directa & 30 & \\
\hline Navicula sp. & 26 & \\
\hline Nitzschia angulata + & 28 & 9 \\
\hline N. closterium* & 1 & \\
\hline N. curta* + & 5 & 1 \\
\hline N. cylindrus* + & 2 & 2 \\
\hline N. heimii* & 8 & \\
\hline N. kerguelensis + & & 4 \\
\hline N. lecointei & 21 & \\
\hline N. lineola & & 29 \\
\hline N. obliquecostata+ & 17 & 6 \\
\hline N. panduriformis & & 38 \\
\hline N. prolongatoides & 20 & \\
\hline N. pseudonana & 22 & \\
\hline N. ritscheri* + & 9 & 7 \\
\hline N. separanda & 38 & 13 \\
\hline N. spp. & 30 & \\
\hline N. subcurvata & 11 & \\
\hline N. sublinearis & & 12 \\
\hline N. sublineata & 13 & \\
\hline N. turgiduloides & 15 & 22 \\
\hline Odontella weissflogii & 30 & \\
\hline Porosira glacialis (rsp) & & 14 \\
\hline P. pseudodenticulata & 34 & 38 \\
\hline Rhizosolenia alata & 16 & 30 \\
\hline R. hebetata f. semispina & 33 & 22 \\
\hline$R$. hebetata f. bidens & 38 & \\
\hline Stellarima microtrias & 41 & 19 \\
\hline Synedra sp. & 38 & \\
\hline Thalassionema sp. & 38 & \\
\hline Thalassiosira frenguelliopsis & 38 & \\
\hline T. gracilis + & 10 & \\
\hline T. gracilis var. expecta & 21 & \\
\hline T. gravida & 38 & \\
\hline T. lentiginosa & 16 & \\
\hline T. oliverana & 38 & \\
\hline T. perpusilla & 38 & \\
\hline T. ritscheri, fasciculated & 38 & \\
\hline Thalassiosira sp. & 14 & \\
\hline Thalassiosira spore & 11 & \\
\hline T. trifulta & 38 & \\
\hline T. tumida, linear + & 5 & \\
\hline Thalassiothrix longissima & 25 & \\
\hline Trichotoxon reinboldii & 14 & \\
\hline Tropidoneis antarcticus & 40 & \\
\hline$T$. beligicase & 36 & \\
\hline T. glacialis & 23 & \\
\hline T. sp. cf. vanheurckii & 12 & \\
\hline Pennate & & 17 \\
\hline Centric & & 26 \\
\hline \multicolumn{3}{|l|}{ Others } \\
\hline Distephanus speculum & & 24 \\
\hline Chrysophyte cyst + & & 8 \\
\hline
\end{tabular}

Note: * indicates 10 most abundant water column species. + denotes 10 most abundant sediment species. Resting spores denoted as (rsp) and vegetative cells designated as (veg).
Table 4. Ten most common species in plankton and sediment. $\mathbf{R A}=$ relative abundance.

\begin{tabular}{lrlr}
\hline \multicolumn{1}{c}{$\begin{array}{c}\text { Plankton } \\
\text { species }\end{array}$} & RA(\%) & \multicolumn{1}{c}{$\begin{array}{c}\text { Sediment } \\
\text { species }\end{array}$} & RA(\%) \\
\hline Nitzschia closterium & 42.79 & Nitzschia curta & 55.10 \\
N. cylindrus & 39.68 & N. cylindrus & 7.42 \\
Chaetoceros neglectus & 4.58 & Chaetoceros sp. (rsp) & 6.99 \\
Corethron criophilum & 3.32 & N. kerguelensis & 6.01 \\
N. curta & 2.85 & Thalassiosira tumida & 5.69 \\
C. dichaeta & 1.89 & N. obliquecostata & 3.42 \\
C. sp. (rsp) & 0.88 & N. ritscheri & 1.71 \\
N. heimii & 0.75 & N. angulata & 2.20 \\
N. ritscheri & 0.60 & T. gracilis & 1.66 \\
C. sp. cf. wighamii (veg) & 0.48 & T. sp. (rsp) & 1.15 \\
Others & 2.18 & Others & 7.65 \\
\hline
\end{tabular}

Note: rsp indicates resting spore; veg indicates vegetative cell.

Kang and Fryxell (this volume). Initial microscopic observations of the numerous grazers and the abundant fecal pellets within these five sites substantiate that grazing pressures upon the phytoplankton were indeed heavy. Additionally, microscopic examination of living materials at Site 739 revealed that many chains of Chaetoceros, Corethron, and Rhizosolenia were nonfluorescent or empty. Previously unreported, this localized population of Corethron criophilum appeared to be diseased (Fryxell, pers. observation).

\section{DISCUSSION}

Satellite passive-microwave observations of Antarctic sea ice by Zwally et al. (1983) show that the mean monthly sea-ice concentrations are generally greater than $70 \%$ from April to December in Prydz Bay (Middleton and Humphries, 1989). Essentially, open water predominates only in January and early February. Air temperatures are generally below freezing even in summer, with freezing processes being active for most of the year (Middleton and Humphries, 1989). Satellite imagery, furthermore, suggests a slightly longer ice-free period for the inner part of Prydz Bay compared to outer Prydz Bay for the 1987-88 window. Considering these facts, our 3-week occupation of Prydz Bay represented a major portion of the active phytoplankton growing season for 1988. The general water column circulation pattern for Prydz Bay may be described as a closed cyclonic gyre (Smith et al., 1984). Such containment would allow local underlying sediments to receive the bulk of regional primary production from one rotating water mass.

The extremely high concentrations observed in phytoplankton biomass, represented both in cell numbers and in chlorophyll $a$ concentrations, appear substantially elevated when compared to the Southern Ocean as a whole. Our estimates of $10^{10}$ cells $/ \mathrm{m}^{2}$ are slightly higher than those of Kozlova (1966) and Ligowski (1983) for Prydz Bay, both on the order of $10^{8}$ cells $/ \mathrm{m}^{2}$. Bloom proportions in conjunction with a recently receding ice edge and increasing water column stability are suggestive of the austral spring blooms along marginal ice zones (Garrison et al., 1987, Tilzer et al., 1985). The primary agents of this bloom were the three nanoplanktonic pennates Nitzschia cylindrus, Nitzschia closterium, and Nitzschia curta. Although quite common in Antarctic waters, $N$. cylindrus and $N$. closterium have been reported to dominate water column phytoplankton assemblages only by Fryxell and Kendrick (1988) and Garrison et al. (1987). Kozlova (1962) previously observed the dominance of Nitzschia curta in surface waters of Prydz Bay. All three species are also, however, common constituents of sea-ice communities. Nitzschia subcurvata, another ice-related species, was also a common water column inhabitant.

Garrison et al. (1987) have demonstrated strong similarities between ice and planktonic algal assemblages in the vicinity of 
Table 5. Standing crop of planktonic diatoms and the relative contributions of the dominant diatom species. Mean total diatom abundances given as $\times 10^{9}$ cells $\mathrm{m}^{-2}$. Relative abundances of diatoms in the water column and in the sediments.

\begin{tabular}{lccccccrr}
\hline Site & $\begin{array}{c}\text { Mean } \\
\text { total }\end{array}$ & $\begin{array}{c}\text { N. closterium } \\
\text { (\% of total) } \\
\text { Water }\end{array}$ & $\begin{array}{c}\text { N. cylindrus } \\
\text { (\% of total) } \\
\text { Sediment }\end{array}$ & $\begin{array}{c}\text { N. curta } \\
\text { (\% of total) } \\
\text { Water }\end{array}$ & $\begin{array}{c}\text { Large-celled } \\
\text { diatoms } \\
\text { Sediment }\end{array}$ & Water & Sediment & (\% of total) \\
\hline 739 & 287.87 & 65.3 & 0.0 & 28.0 & 7.15 & 2.40 & 59.83 & 2.7 \\
740 & 261.75 & 32.8 & 0.0 & 48.5 & 8.91 & 6.50 & 68.22 & 13.7 \\
741 & 180.10 & 21.5 & 0.0 & 39.3 & 7.74 & 3.44 & 65.48 & 33.7 \\
742 & 117.94 & 52.8 & 0.0 & 37.0 & 7.49 & 6.02 & 55.73 & 2.6 \\
743 & 37.64 & 10.4 & 0.0 & 77.1 & 5.79 & 3.43 & 30.58 & 1.0 \\
\hline
\end{tabular}

Leg 119 Site 740

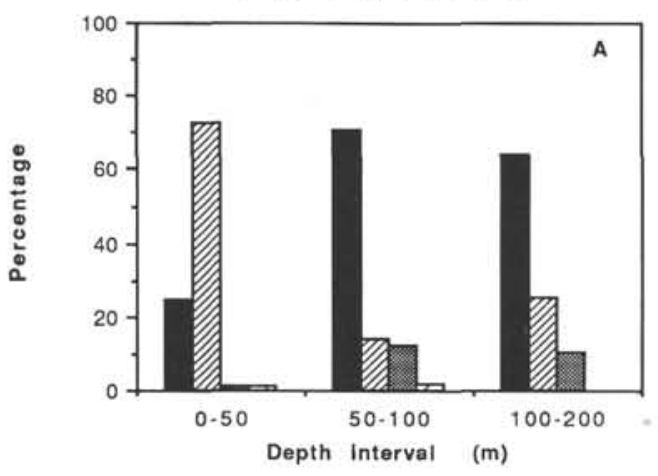

Leg 119 Site 741

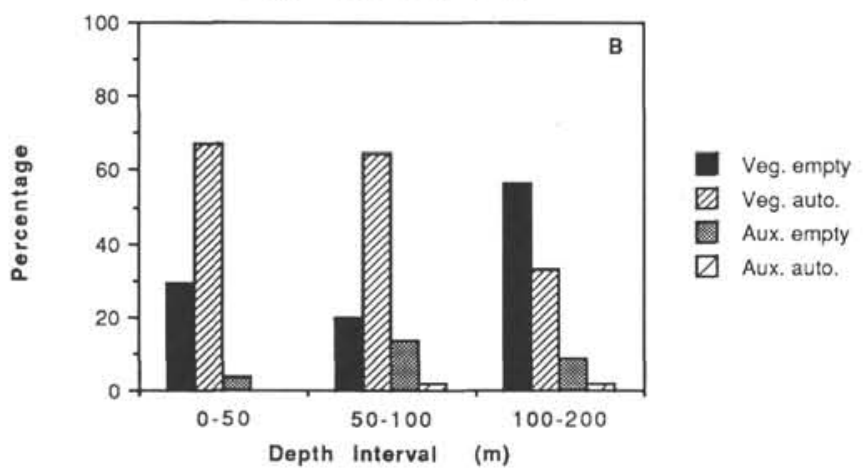

Leg 119742

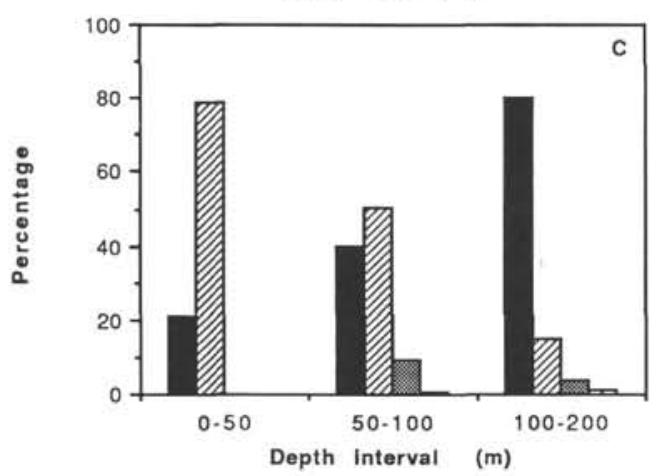

Figure 2. Distribution of the relative proportions of Corethron criophilum life stages (vegetative cells vs. auxospores), shown with respect to depth. Condition of cells, as determined by autofluorescence, indicate full or empty cells. recently receded ice edge systems. In addition, mechanisms for bloom initiation within these marginal ice zones have been discussed by Smith and Nelson (1985). Our occupation of Prydz Bay occurred following the disappearance of local pack ice. The intense bloom conditions encountered exemplify the short growing season characteristic for this embayment. The phytoplankton community, as a whole, appeared dominated by ice-related, nannoplanktonic diatoms, although local variations in both biomass and in species composition were observed.

El-Sayed and Turner (1977) reported chlorophyll $a$ concentrations for Antarctic waters to average $17.4 \mathrm{mg} / \mathrm{m}^{2}$ (range $0.23-337.7 \mathrm{mg} / \mathrm{m}^{2}$ ) when integrated over the euphotic zone. Holm-Hansen et al., (1977) found integrated chlorophyll $a$ concentrations in the upper $200 \mathrm{~m}$ to average $10.45 \mathrm{mg} / \mathrm{m}^{2}$ (range $0.73-30.8 \mathrm{mg} / \mathrm{m}^{2}$ ). These values suggest that spring Prydz Bay phytoplankton biomass was substantially elevated when compared to the Southern Ocean as a whole over much of the icefree season. Additionally, grazing pressures on this population were heavy as evidenced by numerically abundant diatom-laden fecal pellets (pers. observation).

Diatom frustules in the clayey sediments of Prydz Bay were abundant, as previously reported (Kozlova, 1966). Our values are more directly comparable to the concentration range reported by Kozlova (1966) for the clayey-diatom oozes of Prydz Bay (13.6-111 $\times 10^{6}$ frustules/g). These values are slightly higher than the range of frustules found for typical Antarctic iceberg sediments of the continental shelf $\left(0.55-50 \times 10^{5}\right.$ frustules/g) as reported by Kozlova (1962) and Krebs (1977). The genus Nitzschia typically formed $70 \%$ of the diatom thanatocoenose within these sediments, but the species dominance differed from that seen in the plankton. The coastal or neritic species, $N$. curta, was the dominant organism within Prydz Bay sediments. Kozlova (1966) described N. curta as a diatom noted for its mass occurrences in the plankton of coastal regions and having a good capacity for preservation. The lightly silicified $N$. closterium, dominating the water column populations, was not observed in sediment samples. Another substantial contributor to the sediment assemblage was $N$. cylindrus. Two of the three dominant water column species, therefore, were able to survive selective dissolution and sedimentation processes to also dominate the sediments. It should be noted, however, that the relative contributions of $N$. cylindrus to the total sediment assemblage appeared very much reduced when compared to the planktonic contributions. Subsequent analysis of sediments downcore also indicated that the heavily silicified resting spores of Chaetoceros can account for approximately $8 \%-34 \%$ of Prydz Bay sediment assemblages. The genus Chaetoceros is a common planktonic form that has been poorly represented by vegetative forms within the sediment.

The diatom concentrations in the sediments of Prydz Bay reflected the short-lived but intense productivity patterns of the overlying surface waters. Additionally, diatom numbers within this system appear high because there is little influx of terrige- 
nous materials to dilute concentrations (Kozlova, 1966). During the process of sedimentation, water column diatom assemblages undergo selective dissolution. Selective mechanical and chemical destruction of frustules reduces absolute diatom concentrations within these sediments.

Species composition, likewise, undergoes a distinct, selective alteration. Common within water column assemblages, the lightly silicified species such as Nitzschia closterium, Chaetoceros neglectus, Chaetoceros flexuosus, and Tropidoneis sp. are not observed in the sediments. Mechanical breakage of Corethron criophilum and Chaetoceros dichaeta reduced their appearances within the sediments. Krebs (1977) found this selective preservation to favor the more heavily silicified benthic diatoms of Arthur Harbor, Antarctica. Benthic species were not common components of the Prydz Bay materials. The deep water nature of our sampling sites precluded their occurrence in favor of a more planktonic regime. The benthic species Cocconeis imperatrix, however, did make an appearance in the sediments closer inshore (Sites 740 and 741).

In general, the observed diatom composition of Prydz Bay sediments had some similarities to that observed over a 3-week period for the water column assemblages. Abundant remains of well-preserved diatoms were deposited beneath areas of recurrent high productivity. Both of the assemblages were typically dominated by ice-related pennates less than $20 \mu \mathrm{m}$ in size. Another important sedimentary component, the robust Chaetoceros resting spores, were also usually less than $20 \mu \mathrm{m}$. An increase in larger-celled diatoms at Sites 740 and 741 may indicate conditions of increased ice-free periods. Further information is needed before correlations to ice coverage may be extended to sediment samples. Although selective preservation of frustules was apparent, such removals did not seem to greatly affect diatom diversity within the sediments. Apparently, the sediments of Prydz Bay reflect in the diatom assemblage the intense but short-lived growing season in a semi-enclosed gyre that makes it an ideal area for comparison.

\section{CONCLUSIONS}

Local variations in biomass and in species composition were observed for the Prydz Bay water column during our sampling period. Although a closed gyre, the effects of water column stability and ice coverage need to be examined in further detail with respect to species distributions and abundances. The diatom concentrations within the underlying near-surface sediments also reflected the short-lived but intense productivity pulses of the plankton. Mirroring the water column, sediment assemblages were characterized by a grouping of small, ice-related forms. Total diatom abundances decreased moving out of Prydz Bay, both in water column and sediment assemblages. Although Nitzschia curta dominated these near-surface sediment assemblages, selective dissolution removed or reduced in numbers 5 of the 10 most common species within the plankton. The importance of water column dominants, such as Nitzschia closterium, $N$. cylindrus, and Corethron criophilum, were greatly reduced with sedimentation. Quantification of the processes regulating selective preservation of diatom assemblages over the course of geological time are essential for future resolution of paleoclimate and further paleo-ecological interpretations.

\section{REFERENCES}

Barron, J., Larsen, B., et al., 1989. Proc. ODP, Init. Repts., 119: College Station, TX (Ocean Drilling Program).

Edwards, D. S., and Goodell, H. G., 1969. The detrital mineralogy of ocean floor surface sediments adjacent to the Antarctic Peninsula, Antarctica. Mar. Geol., 7:207-234.
El-Sayed, S. Z., 1970. On the productivity of the Southern Ocean (Atlantic and Pacific sectors). In Holdgate, A. (Ed.), Antarctic Ecology (Vol. 1): New York (Academic Press), 119-135.

El-Sayed, S. Z., and Turner, J. T., 1977. Productivity of the Antarctic and tropical/subtropical regions: a comparative study. In Dunbar, M. J. (Ed.), Polar Oceans. Proc. SCOR/SCAR Polar Oceans Conf. Montreal, 463-504.

Fenner, J., Schrader, H. J., and Wienigk, H., 1976. Diatom phytoplankton studies in the southern Pacific Ocean, composition and correlation to the Antarctic Convergence and its paleoecological significance. In Hollister, C. D., Craddock, C., et al., Init. Repts. DSDP, 35: Washington (U.S. Govt. Printing Office), 757-813.

Fryxell, G. A., and Kendrick, G. A., 1988. Austral spring microalgae across the Weddell Sea ice edge: spatial relationships found along a northward transect during AMERIEZ 83. Deep-Sea Res. Part A, 35: $1-20$.

Garrison, D. L., Buck, K. R., and Fryxell, G. A., 1987. Algal assemblages in antarctic pack ice and in ice-edge plankton. J. Phycol., 23: 564-572.

Holm-Hansen, O., El-Sayed, S. Z., Franzeschini, G., and Cukel, R., 1977. Primary production and the factors controlling phytoplankton growth in the Southern Ocean. In Llano, G. A. (Ed.), Adaptations within Antarctic Ecosystems. Proc. 3rd SCAR Symp. Antarctic Biol. Smithsonian Inst., 11-50.

Kang, S.-H., 1989. Diatom species composition and abundance in water column assemblages from five drill sites in Prydz Bay, Antarctica, Ocean Drilling Program Leg 119: distributional patterns [M.S. thesis]. Texas A\&M Univ., College Station, TX.

Kozlova, O. G., 1962. Species composition of diatoms from waters of the Indian Ocean Sector of the Antarctic. Tr. Inst. Okeanol. AN SSSR, 61:3-18.

1966. Diatoms of the Indian and Pacific Sectors of the Antarctic: Washington, D.C., (N.S.F.). (Translated from the Russian).

Krebs, W. N., 1977. Ecology and preservation of neritic marine diatoms, Arthur Harbor, Antarctica [Ph.D. dissert.]. Univ. California, Davis.

Ligowski, R., 1983. Phytoplankton of the Olaf Prydz Bay (Indian Ocean, East Antarctica) in February 1969). Pol. Polar Res., 4:21-32.

Lisitzin, A. P., 1960. Bottom deposits of the Antarctic. Referativnyi $\mathrm{Zh}$. "Geologiya", 11:21849-25189.

A. P., 1962. Bottom sediments of the Antarctic: Antarctic Research. Am. Geophys. Union, Geophys. Monogr., 7:81-88. 1972. Sedimentation in the World Ocean, with Emphasis on the Nature, Distribution and Behavior of Marine Suspensions. Soc. Econ. Paleontol. Mineral Spec. Publ., 17:81-88.

Middleton, J. H., and Humphries, S. E., 1989. Thermohaline structure and mixing in the region of Prydz Bay, Antarctica. Deep-Sea Res. Part A, 36:1255-1266.

Schrader, H.-J., 1976. Cenozoic planktonic diatom biostratigraphy of the Southern Pacific Ocean. In Hollister, C. D., Craddock, C., et al., Init. Repts. DSDP, 35: Washington (U.S. Govt. Printing Office), 605-672.

Simonsen, R., 1974. The diatom plankton of the Indian Ocean Expedition of $R / V$ "Meteor"1964-1965. "Meteor" Forschungsergeb., Reihe $D, 19: 1-107$.

Smith, N. R., Zhaoqian, D. J., Kerry, K. R., and Wright, S., 1984. Water masses and circulation in the region of Prydz Bay, Antarctica. Deep-Sea Res. Part A, 31:1121-1147.

Smith, W. O., and Nelson, D. M., 1985. Phytoplankton biomass near a receding ice-edge in the Ross Sea. In Siegfried, W. R., Condy, P. R., and Laws, R. M. (Eds.) Antarctic Nutrient Cycles and Food Webs: Berlin (Springer-Verlag), 60-69.

Tilzer, M. M., von Bodungen, B., and Smetacek, V., 1985. Light-dependence of phytoplankton photosynthesis in the Antarctic Ocean: implications for regulating productivity. In Siegfried, W. R., Condy, P. R., and Laws, R. M. (Eds.) Antarctic Nutrient Cycles and Food Webs: Berlin (Springer-Verlag), 60-69.

Zwally, H. J., Campbell, W. J., Carsey, F. D., and Gloersen, P., 1983. Antarctic sea ice, 1973-1976: satellite passive-microwave observations. NASA, Spec. Publ., 459:206.

Date of initial receipt: 29 June 1990

Date of acceptance: 5 July 1990

Ms 119B-205 